\title{
Postcolonial Frameworks with Survivors' Voices: Teaching about contemporary and historical forms of slavery and forced labour
}

Sallie Yea

\begin{abstract}
Much of the information for educating students and the public about human trafficking only involves survivors' direct experiences as brief excerpts from more complex and detailed narratives. In this paper, I draw on a postcolonial framework to argue that sidelining survivors' voices can bolster anti-slavery stakeholders' agendas by selectively using survivors' narratives to illustrate narrow constructions of slavery and forced labour. As part of education and awareness efforts, such approaches to understanding slavery and forced labour also perpetuate stereotypes that trafficked persons are powerless and lack agency. Therefore, I present an alternative educational approach to remedy these tendencies by viewing and discussing narratives by, and about, trafficked persons. This paper uses a universitylevel humanities and social science subject on trafficking and slavery, and related assessment tasks, as a case study to demonstrate the potential of survivors' voices in teaching about slavery.
\end{abstract}

Keywords: education, slavery, human trafficking, history, postcolonialism, agency, representation

Please cite this article as: S Yea, 'Postcolonial Frameworks with Survivors' Voices: Teaching about contemporary and historical forms of slavery and forced labour', Anti-Trafficking Review, issue 17, 2021, pp. 73-90, https://doi.org/10.14197/ atr.201221175

\section{Introduction}

There is now considerable scholarly literature on teaching about human trafficking, slavery, and forced labour, and an extensive literature on the role of representations in anti-trafficking work, including awareness-raising among and education of students, the public, and at-risk groups. It is well documented that educating

This is an open-access article distributed under the terms of the Creative Commons Attribution License (CC-BY). Under the CC-BY license, the public is free to share, adapt, and make commercial use of the work. Users must always pive proper attribution to the authors and the Anti-Trafficking Review. 
about slavery and forced labour-both in their historical and contemporary forms - is encumbered by stereotypes that reproduce narrowly-construed victim and survivor typologies and experiences.

Representations play a central role in educating diverse audiences about slavery and related issues, including human trafficking. The narratives of victims/ survivors $^{1}$ are often popularly depicted in ways that reduce complex and discrepant experiences into a narrow range of 'perfect victim' stereotypes. ${ }^{2}$ Narrowing trafficking to a particular notion of a perfect victim damages efforts to educate people. For example, one prominent stereotype is the conflation of human trafficking with 'sex trafficking' ${ }^{3}$ and a focus on extreme cases of child 'sex slavery'. ${ }^{4}$ Such representations limit understandings of human trafficking, particularly as a phenomenon characterised by a lack of agency by trafficked persons, whilst often privileging anti-trafficking stakeholders' voices and agendas.

To address this educational tendency, in this paper, I argue that learning approaches could benefit from critically engaging with the potential and actual impacts of victim stereotypes, and that survivor narratives are instrumental for dislodging these stereotypes. The case study for this paper emerges from the design and delivery of my senior undergraduate subject, ${ }^{5}$ From Slavery to Human Trafficking, at an Australian university. In my subject, I advance a pedagogical approach to (un) learning about historical and contemporary forms of slavery and forced labour. This approach is grounded in postcolonial perspectives that are woven into the subject content and rationale. Students are introduced to the broad tenets and

1 I use the terms victim and survivor interchangeably in this paper, though I am aware there are differences between them.

2 R Andrijasevic and N Mai, 'Trafficking (in) Representations: Understanding the recurring appeal of victimhood and slavery in neoliberal times', AntiTrafficking Review, issue 7, 2016, pp. 1-10, https://doi.org/10.14197/ atr.20121771; E Kinney, 'Victims, Villains, and Valiant Rescuers: Unpacking sociolegal constructions of human trafficking and crimmigation in popular culture', in M J Guia (ed.), The Illegal Business of Human Trafficking, Springer, Cham, 2016, pp. 87-108, https://doi.org/10.1007/978-3-319-09441-0_7.

3 C S Vance, 'Innocence and Experience: Melodramatic narratives of sex trafficking and their consequences for law and policy', History of the Present, vol. 2, issue 2, 2002, pp. 200-218, https://doi.org/10.5406/ historypresent.2.2.0200; A I Fukushima, Migrant Crossings: Witnessing buman trafficking in the U.S., Stanford University Press, Stanford, 2019.

4 S Yea, Trafficking Women in Korea: Filipina migrant entertainers, Routledge, London, 2015.

5 'Subject' is used in this paper to mean a specific unit of study at university. In some other national contexts, the equivalent term is 'course'. 
goals of postcolonialism, particularly the idea that the history and agency of marginalised subjects can be reclaimed. ${ }^{6}$ Students are encouraged to consider postcolonialism as not only an approach to knowledge and voice, but also as a methodology, which then opens up avenues to analyse discourses that produce and perpetuate stereotypical representations of slavery and human trafficking.

This subject engages students with two types of media that aim to help them understand how and why representations can be both problematic and empowering. First, students view and discuss narratives by former slaves, forced labourers, and trafficked persons. Second, students view documentaries and films about human trafficking and slavery that are authored by actors different from victims/survivors or freed slaves. ${ }^{8}$ These diverse media work to counter existing stereotypes by inserting experiences and voices of survivors, whose narratives can depart markedly from externally-imposed understandings (as will be drawn out in more detail in subsequent sections of this paper). These media also enable students to recognise the role of representations, such as fictional films or docudramas, in organising understandings of victim profiles and scenarios of slavery and human trafficking.

This paper's aim is to provide suggestions for those who are teaching about slavery and forced labour in order to enhance ethical education. This is done by

6 A Loomba, Colonialism/Postcolonialism, $3^{\text {rd }}$ edition, Routledge, London, 2015.

7 L Tuhiwai Smith, Decolonising Methodologies: Research and Indigenous peoples, Bloomsbury, London, 2012.

8 Although this subject discusses a wide range of historical and contemporary expressions of human trafficking, slavery, and forced labour, it very deliberately avoids suggesting equivalence between historical forms of slavery (including chattel slavery and serfdom) and contemporary practices, which are themselves multifidous. In the first week of the subject, students are asked to identify key differences between different types of unfree labour. Student responses are re-visited at key points throughout the subject and in the final week. The purpose of this exercise is to ensure that modern-day slavery and human trafficking are not equated with historical practices. These distinctions are important not only for definitional clarity, but also because of the unhelpful political and policy consequences such conflations can entail. Hill, for example, has detailed the way 'trafficking rhetoric' is used by the government in the United Kingdom to justify restrictive and punitive migration agendas and policies, suggesting that underlying racism becomes an important construct for restrictive migration controls when considered in light of this historical conflation with contemporary human trafficking. See A Hill, 'The Rhetoric of Modern-Day Slavery: Analogical links and historical kinks in the United Kingdom's anti-trafficking plan', philoSOPHIA, vol. 17, no. 2, 2017, pp. 241-260, https://doi.org/10.1353/phi.2017.0023. 
drawing out the role and power of representations, voice, agency, and experiences of survivors of slavery and forced labour, and the role of other stakeholders circulating knowledge — and stereotypes — of slavery, forced labour, and human trafficking. In the next section, I provide a literature review on trafficking education. Then, I offer a brief overview of the subject, From Slavery to Human Trafficking, the degree in which it sits, and the student audience to which it is oriented. The main part of this paper presents the educational approach that guides the subject's focus on agency, voice, and representation in understanding slavery and forced labour, including a description of the assessment tasks associated with this mode of learning. A brief conclusion follows where I consider possible ways to avoid problems emerging from narrow constructions of slavery and human trafficking based on my teaching experience. I also build on the limited literature exploring approaches to classroom teaching about trafficking. ${ }^{9}$

\section{Education about Slavery and Forced Labour}

The literature on anti-trafficking education and related forms of modern-day slavery is diffuse in its targeted audiences and intention. For example, it is often practitioner-oriented, aiming to improve victim identification processes and interventions by diverse groups of professionals, including nurses, ${ }^{10}$ social workers, ${ }^{11}$ and law enforcement. ${ }^{12}$ Education in tertiary settings is not necessarily disassociated from practical actions, such as reducing personal risk and improving

9 See, for example, M Dragiewicz, 'Teaching about Trafficking: Opportunities and challenges for critical engagement', Feminist Teacher, vol. 18, no. 3, 2008, pp. 185-201, https://doi.org/10.1353/ftr.0.0007; and N B Busch-Armendariz, M Nsonwu, and L Cook Heffron, Human Trafficking: Applying research, theory, and case studies, Sage, Los Angeles, 2017.

10 P Arulrajah and S L Steele, 'UK Medical Education on Human Trafficking: Assessing uptake of the opportunity to shape awareness, safeguarding and referring in the curriculum', BMC Medical Education, vol. 18, article no. 137, 2018, https://doi.org/10.1186/s12909-018-1226-y.

11 J Thompson and M Haley, 'Human Trafficking: Preparing counselors to work with survivors', International Journal for the Advancement of Counselling, vol. 40, issue 3, 2018, pp. 298-309, https://doi.org/10.1007/s10447-018-9327-1.

12 A Farrell, R Pfeffer, and K Bright, 'Police Perceptions of Human Trafficking', Journal of Crime and Justice, vol. 38, issue 3, 2015, pp. 315-333, https:/ / doi.or g/10.1080/0735648X.2014.995412. 
victim identification. ${ }^{13}$ Further, anti-trafficking education conducted by nongovernment organisations may have as a key objective garnering support or raising funds to further the work of particular organisations or groups. Education by anti-trafficking organisations has been subject to scrutiny for its potential to distort the issue of human trafficking, and to use trafficking as a means of gaining (and misappropriating) funds. ${ }^{14}$ There is also an increasing number of celebrity interventions in the construction of knowledge about victims of trafficking, with these famous individuals relying on their status to influence campaigns to counter trafficking. ${ }^{15}$

Despite the steady increase in education and awareness-raising about human trafficking and modern-day slavery, there is currently no compiled, international database listing the number or orientation of awareness-raising activities. Nonetheless, several studies have critically reviewed individual campaigns. ${ }^{16}$ In a review of the literature, Szablewska and Kubacki identified problems with

13 M Lemke, "Educators as the "Frontline" of Human-Trafficking Prevention: An analysis of state-level education policy', Leadership and Policy in Schools, vol. 18, issue 3, 2019, pp. 284-304, https://doi.org/10.1080/15700763.2017.13 98337.

14 E Shih, 'Freedom Markets: Consumption and commerce across human trafficking rescue in Thailand', Positions, vol. 25, issue 4, 2017, pp. 769-794, https://doi.org/10.1215/10679847-4188410.

15 S Majic, 'Publicizing the (In)visible? Celebrities, anti-human trafficking activism, and feminist ideologies', Social Politics: International Studies in Gender, State and Society, vol. 28, issue 1, 2021, pp. 94-108, https://doi.org/10.1093/ sp/jxz040; S Majic, 'Real Men Set Norms? Anti-trafficking campaigns and the limits of celebrity norm entrepreneurship', Crime, Media, Culture, vol. 14, no. 2, 2018, pp. 289-309, https://doi.org/10.1177/1741659017714518; S L Steele and T Shores, 'More Than Just a Famous Face: Exploring the rise of the celebrity expert-advocate through anti-trafficking action by the Demi and Ashton Foundation', Crime, Media, Culture, vol. 10, issue 3, 2014, pp. 259-272, https://doi.org/10.1177/1741659014558434.

16 Steele and Shores; S Yea, 'Girls on Film: Affective politics and the creation of an intimate anti-trafficking public through film screenings in Singapore', Political Geography, vol. 45, 2015, pp. 45-54, https://doi.org/10.1016/j. polgeo.2014.08.009; S Stiles, 'I Am Elena: Rhetorical analysis as the first step to a "best practices" formula for sex trafficking public service announcements', Visual Communication, vol. 11, issue 2, 2012, pp. 185-206, https://doi. org/10.1177/1470357211434031; C Nieuwenhuys and A Pécoud, 'Human Trafficking, Information Campaigns, and Strategies of Migration Control', American Behavioural Scientist, vol. 50, issue 12, 2007, pp. 1674-1695, https:/ / doi.org/10.1177/0002764207302474. 
information and education campaigns, which are key concerns that motivate my interest in critical approaches to learning about trafficking. As they state, 'a thematic analysis of the studies identified problems in eight areas that require attention in the future development of anti-human trafficking campaigns: stereotyping, compounding human trafficking with migration, conflating prostitution with human trafficking, sexualization/erotization of women, victimization, role of anti-human trafficking organizations, data shortcomings, and oversimplification of human trafficking. ${ }^{17}$ From Slavery to Human Trafficking attempts to develop an approach to knowledge about slavery and forced labour that moves beyond frames that may (inadvertently) reinforce the stereotypes we seek to recognise and challenge.

\section{Postcolonial Frameworks in Education about Slavery}

At secondary and tertiary levels, there is a significant debate about the methods and content of history education in the Australian curriculum, which varies from state to state since education is a state portfolio. This controversy is particularly pronounced in relation to Australian history but also relating to particular aspects of world history, including war and conflict, slavery, human rights, and race. ${ }^{18}$ In the last decade, debate has focused on the importance of education in decolonising Australia's histories of slavery, not only acknowledging episodes of slavery, but also enabling the voices of Indigenous and Pacific Islander scholars, advocates,

17 N Szablewska and K Kubacki, 'Anti-Human Trafficking Campaigns: A systematic literature review', Social Marketing Quarterly, vol. 24, issue 2, 2018, pp. 104-122, p. 104, https://doi.org/10.1177/1524500418771611.

18 The debates reached a public crescendo in early 2020 when Prime Minister Scott Morrison commented on the \#BlackLivesMatter movement, declaring how fortunate Australia was to not have a history of slavery. The backlash to Morrison's comments came from academics and activists alike, who were concerned about the Prime Minister's elision of the slavery of Indigenous Australians, the bonded labour of Pacific Islanders under the Blackbirding schemes of the late nineteenth and early twentieth centuries, and the more recent episodes of forced labour and slavery in the sex industry and beyond it. Indigenous Labour politician and spokeswoman for Indigenous Affairs, Linda Burney, commented that Morrison should better understand Australian history. See, M Koslowski, “'It’s Just Denial”: Bruce Pascoe, Labour condemns PM's “no slavery in Australia” claim', Sydney Morning Herald, 11 June 2020, retrieved 22 November 2020, https://www.smh.com.au/politics/federal/ it-s-just-denial-bruce-pascoe-labor-condemn-pm-s-no-slavery-in-australiaclaim-20200611-p551jo.html. 
and survivors to be audible within the curriculum. ${ }^{19}$

Education can have a decolonising potential. I suggest that questions about the political stakes of learning should therefore carry equal weight as subject content. Further, education should demonstrate knowledge acquisition and a commitment to postcolonial principles that challenge the 'production and reproduction of marginalised racial, and gendered others in new contemporary times. ${ }^{20}$ Scholarly work on race, memory, and agency in education by researchers Heidi Mirza, ${ }^{21}$ and Leon Tikly and Tim Bond, ${ }^{22}$ inform the shape of this subject by incorporating approaches to learning based on critical readings of historical texts and contemporary media. Simultaneously, recent scholarship on the role of biographical narratives authored or produced by marginalised individuals and groups informs this subject by foregrounding the voices and experiences of survivors themselves. Andrews, for example, reflects on the value of slave narratives in challenging perspectives of slavery emerging from accounts by historians. ${ }^{23}$ He draws attention to the ways that slave narratives indicate the importance of caste and class in illuminating the living conditions of slaves and the intra-community dynamics among slaves. Coletu analyses the role of autobiographical and personal narratives and argues that questions of political economy should be kept in mind when using narratives in education because exposure and disclosure can lead to surveillance by subjectification to a bureaucratic gaze. ${ }^{24}$ The type of intervention made by Coletu is important for asking not only why to draw on these narratives, but also how their use may have political implications that exceed their telling.

19 L Tikly, 'Education and the New Imperialism', in R S Coloma (ed.), Postcolonial Challenges in Education, vol. 369, Peter Lang Publishers, New York, 2009, pp. 23-45.

20 H S Mirza, 'Plotting a History: Black and postcolonial feminisms in "new times", Race, Ethnicity and Education, vol. 12, issue 1, 2009, pp. 1-10, p. 1, https://doi.org/10.1080/13613320802650899.

21 Ibid.

22 L Tikly and T Bond, 'Towards a Postcolonial Research Ethics in Comparative and International Education', Compare: A Journal of Comparative and International Education, vol. 43, issue 4, 2013, pp. 422-442, https://doi.org/10.1080/030 57925.2013.797721.

23 W L Andrews, 'Caste and Class in Nineteenth Century Slave Narratives', $a / b$ : Auto/Biography studies, vol. 32, issue 2, 2017, pp. 225-227, https://doi.org/1 0.1080/08989575.2017.1288003.

24 E Coletu, 'Introduction Biographic Mediation: On the uses of personal disclosure in bureaucracy and politics', Biography, vol. 42, no. 3, 2019, pp. 465-485, https://doi.org/10.1353/bio.2019.0055. 


\section{From Slavery to Human Trafficking: Critical histories}

From Slavery to Human Trafficking is a semester-long subject for undergraduate students in the academic discipline of History, but the subject attracts enrolments from other Humanities and Social Science departments, including Legal Studies, Sociology, Politics, and Geography/Planning. It is run annually at La Trobe University across all campuses and normally attracts well over one hundred enrolees. It consists of a combination of lectures, tutorial discussions, and online activities. Each week, students are introduced to a new topic, with the organisation of the subject following an historical timeline. The subject assumes no prior knowledge of human trafficking or slavery, and so the design needed to try to balance a broad geographical and historical scope with specific and detailed materials within each topic. The topics are as follows:

- Topic 1 is a general introduction that provides definitions of the key terms, including slavery, human trafficking, forced labour, and debt bondage, as well as introducing debates on researching human trafficking and estimating its scale and scope;

Topic 2 overviews slavery in the Ancient World, with a focus on Ancient Greece and Rome;

- Topic 3 provides an introduction to slavery and Indigenous Peoples, with a case study focus on Native American slavery practices;

- Topics $4 \& 5$ focus on the transatlantic slave trade and the antebellum United States

- Topics $6 \& 7$ focus on slavery in Australia;

- Topic 8 examines slavery during wartime through a focus on forced labour of prisoners of war and sexual slavery of the Comfort Women;

- Topic 9 examines the links between human trafficking and disasters, including displacement through conflict and as a result of climate change;

- Topic 10 explores trafficking for forced labour through four case studies that include agricultural, construction, paid domestic work, and global fishing industries;

- Topic 11 examines organ trafficking/the commercial brokering of organs, with the kidney trade in the Philippines acting as the main case study;

- Topic 12 provides an overview of how slaves and victims of trafficking leave these situations and what their post-trafficking/-slavery trajectories are.

By selecting historical and geographical representations of slavery and human trafficking, the subject explores their origins and historical development and manifestations across time and different geographical and cultural contexts. From Slavery to Human Trafficking contains a series of key themes, with the most relevant for discussion in this paper being: agency/voice, experiences and trajectories, responses/anti-slavery, memory/memorialisation, and (dis)continuities in 
historical and contemporary slavery. Additionally, students receive guiding questions that elaborate on these themes in the context of each week's topic.

The key themes and guiding questions provide a basis for students' critical engagement with issues of voice, agency, and representation in human trafficking and slavery, both historically and at present. The guiding questions are:

- How do we learn about the experiences of enslaved people and survivors of human trafficking?

- How do sources (historical and contemporary) realise these understandings?

- What does the diversity of experiences and situations of slavery and human trafficking tell us about economic, social, and cultural contexts?

- How is slavery remembered and memorialised? Who is excluded or silenced?

These questions are amended each week to align more closely with the specificities of each week's topic (discussed further in the next section).

\section{Teaching about Trafficking: Agency, voice, and representation}

In this section, I discuss the use of two different types of narratives about slavery and human trafficking in the educational material. I draw on examples from four of the twelve weekly topics in From Slavery to Human Trafficking to illustrate the role and use of materials: survivor-authored narratives, and narratives about trafficking produced by anti-trafficking stakeholders.

\section{Survivors' Voices in Learning About Slavery and Human Trafficking}

The subject introduces narratives of former slaves and survivors of trafficking in all weekly topics, but they are foregrounded most fully in the topics of the antebellum United States, the Comfort Women during World War II, contemporary forced labour, and the relationship between displacement and human trafficking. ${ }^{25}$ In the topic of the antebellum US, issues of agency and voice of formerly enslaved people are most explicitly introduced, drawing on Solomon Northup's narrative, 12 Years a Slave. Students are introduced to Northup's written narrative about his life as a slave and the film based on his narrative. The description of the topic is provided as follows:

25 For the Australian context, students are introduced to the documentary Servant or Slave (2016, SBS Australia) which narrates the story of siblings separated from each other and removed from their parents under Australia's policy of 'Aboriginal Protectionism' in the first half of the twentieth century. 
The narratives of slavery are often obscured in both historical and contemporary understandings of slavery and human trafficking. The antebellum United States, along with countries such as Brazil (where slavery was also widespread and profoundly violent), have produced some rich and detailed accounts of slavery by former slaves themselves. ... This week we examine one of these narratives: Solomon Northup's memoir, 12 Years a Slave, which was made into a full-length film in 2013. Solomon Northup was a New York State-born free African American man who was kidnapped in Washington, D.C. by two conmen in 1841 and sold into slavery. Northup was put to work on plantations in the state of Louisiana for 12 years before being released.

The guiding questions for student discussion of the film and selections of Northup's written narrative include:

- Agency \& Representation: How do narratives of slavery differ between scholarly and popular accounts?

- Experiences of Slavery: What new insights about the experience of slavery are learned through filmic representation? How are differences between the various roles that produce systems of enslavement represented (owners, overseers, managers, and so on)?

- Gender \& Aspects of Identity: In what ways does gender impact experience and representation?

- Agency \& Resistance: What forms does resistance to slavery take in representation and what are the results?

These questions link to the key themes of the subject: particularly voice, representation, and agency; and gender. To support students' critical engagement with 12 Years a Slave, the preceding week introduces the transatlantic slave trade and the antebellum United States in general terms. Secondary readings foreground how slaves were able to exercise agency, shape a sense of identity, and resist the violence of their owners. The readings discuss slave truancy and practices of 'everyday resistance ${ }^{26}$ on US plantations, with a particular focus on the ways these practices are distinctly gendered, and shape slave identity in positive terms, and demonstrate that resistance practices need not always take the form of open

26 J C Scott, Domination and the Arts of Resistance: Hidden Transcripts, Yale University Press, New Haven, 1990. 
defiance and slave rebellion. ${ }^{27}$ Introducing gendered experiences of slavery and resistance prompts students to recognise distinctive experiences, dislodging constructions of a singular slave trajectory or persona. The topic question focused on the differences between slave owners and other non-slave characters in 12 Years a Slave, thereby extending the discussion of difference and disjuncture between non-slave characters and reinforcing the suggestion that plantation identities are complex and irreducible to stereotypes of slave and master. A fourth reading for this topic discusses several key Anglo characters in 12 Years a Slave and provides insights into the various motivations for purchasing a slave, and the financial and social circumstances of slave owners in the United States. ${ }^{28}$ The themes introduced in the topic of the antebellum United States on agency, voice, and representations are reaffirmed and extended by the topic of the Comfort Women, which relates the violence of Japanese colonisation in the Asia-Pacific region and the Pacific theatre of World War II. The experiences of the Comfort Women are situated in the broader historical context of Japanese colonisation of, and expansionism in, the Asia-Pacific. ${ }^{29}$ Key questions for students in this topic are:

- Agency \& Resistance: What do the narratives of former prisoners of war and former Comfort Women tell us about the experiences of being slaves during wartime? And how do these narratives add to and extend scholarly accounts?

- Justice, Memory \& Evidence: What are some of the ways former Comfort Women have sought to realise justice? And to what extent has testimony and 'evidence' played a role in this process?

Students are given a link to oral testimony by former Comfort Woman Kim Bok Dong, ${ }^{30}$ and written narratives of or by several other women, ${ }^{31}$ which were

27 'Beyond the Plantation' (Chapter Three) in S Lussana, My Brother Slaves: Friendship, masculinity and resistance in the antebellum South, University of Kentucky Press, Lexington, 2016, pp. 71-98; S M H Camp, "I Could Not Stay There”: Enslaved women, truancy and the geography of everyday forms of resistance in the antebellum plantation South', Slavery and Abolition, vol. 23, issue 3, 2002, pp. 1-20, https://doi.org/10.1080/714005245.

28 W Johnson, Soul by Soul: Life inside the antebellum slave market, Harvard University Press, Cambridge, 1999, pp. 78-116.

29 As in K H Chen, Asia as Method: Toward deimperialization, Duke University Press, Durham, 2010.

30 Stephen Park, 'Life as a "Comfort Woman": Story of Kim Bok-Dong', Asian Boss, 28 October 2018, retrieved 4 August 2021, https:/ /www.youtube.com/ watch?v=qsT97ax_Xb0\&t $=43 \mathrm{~s}$.

31 Asian Women's Fund, 'Testimonies of the Victims', Digital Museum: The Comfort Women Issue and the Asian Women's Fund, n.d., retrieved 16 November 2020, https://www.awf.or.jp/e3/oralhistory-00.html. 
later published as a book. ${ }^{32}$ The introduction of the Comfort Women as a topic also enables students to debate the role of advocacy and support organisations in representing human trafficking and slavery. These forms of intervention are particularly fraught in discussions of 'sex slavery'33 because of the tendency to equate human trafficking with trafficking for commercial sexual exploitation and slavery with sex slavery. The principal organisation claiming to advocate for the former Comfort Women is the Korean Council for Women Drafted for Military Sexual Slavery by Japan (hereafter, the Korean Council). Sarah Soh's book $^{34}$ challenges the Korean Council's representation of the Comfort Women, including the construction of a nationalist narrative of Korean victimhood and Japanese aggression and invasion. Soh also critiques the selective use of narratives by former Comfort Women to advance this nationalist victim agenda. During this topic, students engage with questions of representation and the appropriation of victimhood narratives that serve broader organisational and national agendas. This appropriation is crystallised in discussions around the Korean Council's advice to former Comfort Women to reject compensation offered under a private Japanese fund. This topic illustrates the ways interest groups can influence the representation of an issue and use narratives of victims of slavery to pursue a particular advocacy agenda.

The final example of critical learning given in this paper is developed through a topic on trafficking for forced labour. This topic contains case studies of forced and trafficked labour within the agricultural, construction, paid domestic work, and global fishing industries. Students can choose one case study to engage with in detail through visual media and published academic work; however, the case study of the construction industry is the core sector with which all students engage. The male construction workers' narratives introduced here emphasise the mundane aspects of exploitation, such as the relationship between everyday experiences and broader structural regimes of immigration and labour that enable the conditions by which marginality and exploitation are reproduced. Students reflect on these narratives and are encouraged to reflect on the fact that, despite legislative and policy tools criminalising human trafficking, labour exploitation continues to exist and flourish within the regimes that govern international labour migration. For many students, that human trafficking exists beyond the sex industry and is applicable to men and boys as well as women and girls is, in

32 K Howard, True Stories of the Korean Comfort Women, Cassel, London, 1996.

33 L M Agustín, Sex at the Margins, Zed Books, London, 2007.

34 C S Soh, The Comfort Women: Sexual violence and postcolonial memory in Japan and Korea, University of Chicago Press, Chicago, 2008. 
itself, a startling revelation. ${ }^{35}$

Whilst all case studies centre the narratives of trafficked persons, the suggestion that trafficked persons' voices are valuable and insightful is brought to the fore most fully in the case study of migrant construction workers. Beyond the core secondary reading provided for the construction sector case study, students are assigned chapters from a series of edited volumes of migrant construction worker diaries and recounts. ${ }^{36}$ The volumes are the primary outputs of a scholar-activist project to provide a forum for precarious migrant workers to articulate their experiences on their own terms and through their own frames of reference via detailed written narratives. This aim is explained in the introduction to the third volume:

The Diaries Project explores the everyday aspects of exploitation of transient migrant workmen from South Asia in Singapore, particularly after they exit exploitative workplaces to pursue remedial justice. Whilst there is an increasing number of scholarly and popular accounts of migrant workers in Singapore and elsewhere, it is almost impossible to find any that are written by workers themselves. We believe opportunities for transient migrant workers to articulate their experiences through a range of forums and modes of expression are an important step in dislodging their mutability and redressing discrimination towards them. The inability of migrant workers to narrate their own stories on their own terms can unwittingly reinforce policies and practices that continue to marginalize them in Singapore, by supporting stereotypes of them as uneducated or only as sources of 'cheap labour' and not individuals with multi-faceted lives, interests, relationships and cultural repertoires. ${ }^{37}$

35 It is emphasised to students that the case study of men and boys as labour trafficking victims should not be read as meaning 'only men and boys are trafficked for labour exploitation, while women and girls are trafficked for sexual exploitation'. The inclusion of a case study on migrant domestic workers in this topic helps situate labour exploitation as a problem that is not gender-exclusive.

36 S Yea, B Balakrishnan, and D Fordyce (eds.), A Thousand and One Days: Stories of migrant worker hardship in Singapore, Volume 3, Thirumagal Publications, Kuala Lumpur, 2018; S Yea, R Haque, and D Fordyce, A Thousand and One Days: Stories of migrant worker hardship in Singapore, Volume 2, Bangla Kantha Publications, Dhaka, 2015; S Yea, A K M Mohsin, and D Fordyce, A Thousand and One Days: Stories of migrant worker hardship in Singapore, Volume 1, Bangla Kantha Publications, Dhaka, 2013.

Ibid., Volume 3, p. 2. 
Through the reading of selected chapters by Bangladeshi and Tamil construction workers in Singapore, reading these volumes aims to reinforce the importance of transnational labourers' voices. Students reflect on the processes by which migrant labourers become unfree through an engagement with narratives of forced labour and human trafficking by the migrants themselves. Additionally, students are introduced to feminist participatory action research principles used by several anti-trafficking NGOs, including the Global Alliance Against Traffic in Women (GAATW). ${ }^{38}$ The narratives of the South Asian migrant construction workers serve another important role in this subject: namely, challenging reductionist stereotypes of human trafficking as a problem that applies principally to the sex industry, which privileges the victimhood of women and girls, and rests on cases of extreme violence and unfreedom. Situating the experience of human trafficking through frames that foreground it in sectors outside of the sex industry supports LeBaron's understanding of unfree labour, contextualising the problem in 'broader relations of inequality and hierarchical social relations'. ${ }^{39}$ In this understanding, unfree labour is not exceptionalised or disembedded from the 'social relationship(s) of insecurity and exploitation' central to capitalist globalisation. This understanding problematises frames of unfreedom that individualise and sensationalise incidents of 'neo-slavery' and are associated with liberal, moral approaches to (sex) trafficking.

There is a risk of continuing to exceptionalise trafficking for commercial sexual exploitation in efforts to foreground labour exploitation in other sectors and amongst groups apart from women and girls. With this in mind, From Slavery to Human Trafficking attends to contemporary expressions of trafficking in the sex industry. First, in the topic on the Comfort Women, the lecture and readings examine the characteristics of sexual slavery in this historical context. Here students are encouraged to consider how sexual slavery manifests during wartime, but also to move beyond stereotypes of sexual violence, physical abuse, and dehumanisation to consider how gender inequality and discrimination created vulnerability causally tied to the recruitment of Comfort Women. Students are introduced to the role of gender inequality in trafficking as a concern that extends beyond the Comfort Women topic through lecture-based content drawing on Cambodia, the Philippines, and Viet Nam as comparative contexts. Second, students are introduced to contemporary expressions of human trafficking in

38 Global Alliance Against Traffic in Women (GAATW), Reclaiming Migrant Women's Narratives: A feminist participatory action research project on "safe and fair" migration in Asia, GAATW, Bangkok, 2019, retrieved 18 November 2020, https://www.gaatw.org/publications / Reclaiming\%20Migrant $\% 20$ Women's\%20Narratives.pdf.

39 G LeBaron, 'Unfree Labour Beyond Binaries: Insecurity, social hierarchy and labour market restructuring', International Feminist Journal of Politics, vol. 17, issue 1, 2015, pp. 1-19, p. 1, https://doi.org/10.1080/14616742.2013.813160. 
South Korea involving US military forces as clientele. Selections from my ${ }^{40}$ and Cheng's ${ }^{41}$ ethnographies of migrant entertainers deployed in bars and clubs around US military bases are provided. The purpose of using a comparative lens in this topic is twofold. First, it enables students to establish the structural and geopolitical embeddedness of global economies of sexual exploitation. ${ }^{42}$ Second, it introduces problems of labour exploitation in ways that draw connections to other forms of exploitation, including commercial sexual exploitation. Through Yea's chapter 'Re-thinking 'Trafficking in gijichon', students consider migrant entertainers' exploitation related to labour conditions issues as well as sexual exploitation. Such a discussion challenges, at least in part, the tendency to create 'silos' in which different forms of human trafficking are treated as entirely separate and unrelated.

In sum, the topics in the subject are organised to centre trafficked persons and former slaves' narratives. The narratives are contextualised through secondary readings that draw out the importance of victims' agency in articulating their experiences and through scholarly analyses of the resistance and re-working practices in which slaves and trafficked persons engage. Through these primary and secondary sources, both historical and contemporary, From Slavery to Human Trafficking unsettles and challenges narrow stereotypes about the gendered and racialised identities of trafficked persons and their experiences as well as the degree of agency which they express. The subject supplants stereotypes by introducing students to the complexities and nuances of trafficked persons and former slaves' lives in ways that foreground their frames of reference and concerns. The subject does use materials produced by people who have not experienced trafficking, including those working for NGOs and community-based organisations (CBOs), and advocating for trafficked and enslaved persons. Students engage with how these advocates construct narratives to serve particular agendas and interests, which helps students to think about how information about trafficking is communicated and for what purposes. Critical engagement skills are built and reinforced through a major assessment task, to which I now turn.

\section{Educational Assessment Tasks to Develop Critical Engagement Skills}

A postcolonial methodology promotes critical reading of dominant representation frames for their colonising potential, while also facilitating modes of representation that work to recover the voices of those subject to this discursive pigeonholing. In this sense, the methodological engagement with voice and representation through students' own work is equally as significant as the subject content. The major

40 Yea, 2015.

41 S L Cheng, On the Move for Love: Migrant entertainers and the U.S. military in South Korea, University of Pennsylvania Press, Philadelphia, 2010.

${ }^{42}$ K Moon, Sex Among Allies: Military prostitution in U.S.-Korea relations, Columbia University Press, New York, 1997. 
assessment task for From Slavery to Human Trafficking takes the form of an in-depth essay, developed to consolidate the key learning outcomes from the topics. The essay allows students the choice of further engaging with representations and narratives of slavery and human trafficking through two question options. The first is a critical textual analysis of a documentary, film, or other work written about human trafficking or slavery. The assignment question for this topic asks students to choose a narrative of slavery or human trafficking and critically examine the way the issue is presented. The essay response should focus on what key themes and tropes are used to represent the issue. The discussion should engage with debates about the potential of anti-slavery and anti-trafficking campaigns to sensationalise the issue, and with the effects that particular narrative constructions of trafficking and slavery can have on responses to the problem.

Students have several options available for analysis, including the films Lilja 4-ever, Fields of Mudan, Buoyancy, and Servant or Slave. Background readings are provided to develop an understanding of scholarly arguments about the potential of human trafficking films and documentaries to create reductionist frames and stereotypes. ${ }^{43}$

The other option for this essay assignment invites students to trace the work of an individual or organisation involved in counter-trafficking or in historical abolitionism. Students can choose from a range of options, including contemporary organisations and individuals, such as the International Justice Mission (IJM), Kevin Bales and Free the Slaves, and GAATW. In analysing these organisations, students may trace the ways in which their moral, religious, or political stance shapes their anti-trafficking work, and with what effects. Within this essay question, students are also given the option of examining an historical figure associated with the historical abolitionist movement, including the former slaves Ottobah Cugoano, Harriet Tubman, Frederick Douglass, and Olaudah Equiano, as well as other actors in the abolitionist movement, including Thomas Paine and William Wilberforce. Through responses to this essay question, students further consider the agency and voice of former slaves as advocates and activists. Befitting the location of the subject in the discipline of History, students are required to include primary sources in their essays, which requires them to read documents written by former slaves themselves (such as Harriet Jacobs' autobiography, Incidents of a Slave Girl, published in 1861). ${ }^{44}$ For some former slaves, who were illiterate and unable to write their own autobiography, the use of ghost writers enables students to gain further insight into the ways slaves' narratives can be selectively edited to meet the goals of various agendas,

43 Yea, 2016; R Andrijasevic, 'Beautiful Dead Bodies: Gender, migration and representation in anti-trafficking campaigns', Feminist Review, vol. 86, issue 1, 2007, pp. 24-44, https://doi.org/10.1057/palgrave.fr.9400355.

44 H Jacobs, Incidents in the Life of a Slave Girl, Thayer \& Eldridge, Boston, 1861. 
including abolition. ${ }^{45}$

In sum, the major assessment task enables students to either critically engage with the work of a former slave or advocate in either the contemporary antitrafficking movement or historically in the abolitionist movement, or to assess the role and impact of representations of human trafficking and slavery. Because of the importance of primary sources in historical research, students are able to engage with a primary text as a source of voice and agency or externally imposed representation. The researching and writing of these essays thus reinforce learnings from weekly topics, and in ways that enable students to pursue particular topics and narratives in ways that reflect their particular interests.

\section{Conclusion}

A postcolonial pedagogy is a political act, at once recognising the coloniality of authoritative representations and challenging the bases of accepted knowledge and authority. ${ }^{46}$ Teaching about trafficking and all forms of slavery and forced labour in a tertiary context begs us to move beyond the acceptance of authoritative discourses, including academic ones, to engage with and challenge the coloniality of power in many accounts of slavery, forced labour, and trafficking. This is important in a post/neo-colonial liberal context, such as Australia, where secret histories of slavery are imbricated with ongoing race-based violence and exploitation. The task of teaching about trafficking through content and methodologies that challenge students to think critically on what constitutes knowledge about slavery and trafficking is a first but important step in developing a postcolonial politics of anti-trafficking that is both subversive and transformative.

Beyond the case study in this paper, there are several ongoing questions that I believe are important to continue debating and discussing in relation to learning about human trafficking in a tertiary education context. Foremost, these questions include whether and to what extent students can take these critical understandings forward in challenging narrow stereotypes about slavery and trafficking, both in their lives and in broader society. For students who go on to work in the antitrafficking sector, institutional change, particularly within the NGO sector, may be difficult at best, especially where anti-trafficking work is intertwined with moral,

45 J Larson, 'Converting Passive Womanhood to Active Sisterhood: Agency, power, and subversion in Harriet Jacobs' "Incidents in the Life of a Slave Girl"', Women's Studies, vol. 35, issue 8, 2006, pp. 739-756, https://doi. org/10.1080/00497870600945618.

46 For a comparative discussion of a transformative pedagogy, see L Bristol, Plantation Pedagogy: A Postcolonial and Global Perspective, Global Studies in Education, Volume 16, Peter Lang Publishing, New York, 2012. 
religious, or nationalist agendas. Further, taking forward critical perspectives on the construction of trafficking victimhood gained through university education can unsettle dominant representations of slavery and trafficking in ways that present challenges to entrenched political positions. Reiterating the complexities of human trafficking may not sit well with the capacity-building training of bureaucrats or NGO actors, for example, who have minimal time or interest in exploring the power of representations and the politics of agency and voice. To address these challenges adequately is beyond the scope of an undergraduate humanities subject. As with any humanities subject, nurturing students' critical thinking and acting provides a corrective to narrow stereotypes of slavery and trafficking, and it is this humble aim to which the subject discussed in this paper aspired.

Sallie Yea is Principal Research Fellow and Associate Professor in the Department of Social Inquiry at La Trobe University, Melbourne. Her teaching and research both focus on modern-day slavery, human trafficking, and forced labour. Her research adopts a feminist geopolitical approach to understandings of these issues. Her current research focuses on justice in cases of 'seafood slavery' and in cases of organ trafficking. She has recently commenced a project examining return from trafficking in the context of COVID-19. Her most recent book, Paved with Good Intentions: Human trafficking and the anti-trafficking movement in Singapore (Routledge, 2019), critically examines Singapore's anti-trafficking movement and its relationship to trafficked persons and forced labourers. Email: salliellao@ gmail.com 